\title{
Virulence of Aeromonas hydrophila to channel catfish Ictaluras punctatus fingerlings in the presence and absence of bacterial extracellular products
}

\author{
Julia W. Pridgeon*, Phillip H. Klesius \\ Aquatic Animal Health Research Unit, USDA-ARS, 990 Wire Road, Auburn, Alabama 36832, USA
}

\begin{abstract}
We investigated the virulence of three 2009 west Alabama isolates of Aeromonas hydrophila (AL09-71, AL09-72 and AL09-73) to channel catfish Ictalurus punctatus fingerlings (4.6 \pm $1.3 \mathrm{~g}$ ) in the presence and absence of extracellular products (ECPs) from overnight bacterial culture using both bath immersion and intraperitoneal injection routes. At a concentration of $1.65 \times 10^{8}$ colony-forming units (CFU) ml- ${ }^{-1}$, AL09-73 without its ECPs killed $100 \%$ of the catfish fingerlings within $2 \mathrm{~h}$ by bath immersion. However, at a similar concentration, AL09-73 in the presence of its ECPs killed only $23 \pm 6 \%$ catfish fingerlings. The absence of ECPs in the bath immersion experiment also significantly $(\mathrm{p}<0.05)$ increased the virulence of AL09-71, AL09-72, and AL98-C1B, a 1998 Alabama strain of $A$. hydrophila, suggesting that the virulence of the 4 A. hydrophila isolates was mainly due to bacterial cells, not to their overnight ECPs. Filter-sterilized ECPs failed to kill any catfish by bath immersion or injection. The virulence order of the 4 A. hydrophila isolates, by both bath immersion and intraperitoneal injection, was: AL09-73 $\geq$ AL09-71 > AL09-72 $\geq$ AL98-C1B. At $2 \mathrm{~h}$ post bath immersion, all 4 isolates of $A$. hydrophila were found in all tissues studied (skin, intestine, liver, spleen, kidney, gill and brain), with the highest bacteria count being in the gill and kidney.
\end{abstract}

KEY WORDS: Aeromonas hydrophila $\cdot$ Extracellular products $\cdot$ Virulence $\cdot$ Bath immersion · Injection

\section{INTRODUCTION}

Aeromonas hydrophila, a Gram-negative motile bacillus widely distributed in aquatic environments, is a causative agent of motile aeromonad septicemia (MAS) (Harikrishnan et al. 2003), also known as epizootic ulcerative syndrome (EUS) (Mastan \& Qureshi 2001). The clinical signs of $A$. hydrophila infections include swelling of tissues, dropsy, red sores, necrosis, ulceration, and hemorrhagic septicemia (Karunasagar et al. 1989, Azad et al. 2001). Fish species affected by MAS include tilapia Oreochromis niloticus (Abd-ElRhman 2009, Tellez-Bañuelos et al. 2010), catfish Ictalurus punctatus (Majumdar et al. 2007, Ullal et al. 2008), goldfish (Irianto et al. 2003, Harikrishnan et al. 2009), common carp (Yin et al. 2009, Jeney et al. 2009), and eel (Esteve et al. 1994). A. hydrophila produces a variety of biologically active extracellular products (ECPs), including aerolysin toxin — which causes holes in cytoplasmic membranes (Howard \& Buckley 1985) - and proteases (Rivero et al. 1990). The crude extracellular products of $A$. hydrophila have been found to possess both hemolytic and proteolytic activity that is lethal to tilapia (Khalil \& Mansour 1997).

Although usually considered as a secondary pathogen associated with disease outbreaks, Aeromonas hydrophila can also become a primary pathogen in some environments, causing outbreaks in fish farms, with high mortality rates and severe economic losses to the aquaculture industry worldwide (Thorpe \& Roberts 1972, Nielsen et al. 2001, Fang et al. 2004). Between June and October 2009, an outbreak of disease occurred in 48 channel catfish farms in west Alabama, USA, causing an estimated loss of $>3$ mil- 
lion pounds (ca. $1400000 \mathrm{~kg}$ ) of food-sized catfish (Hemstreet 2010). The disease produced a variety of symptoms that included sores on the skin, bulging eyes, ulcers, and bright red muscles and internal organs. Diseased catfish were collected by a fish health specialist at the Alabama Fish Farming Center, and bacteria were cultured, isolated, and later identified as A. hydrophila (Hemstreet 2010). Although it was clear that the three 2009 isolates of $A$. hydrophila obtained from the outbreak of disease affect food-sized channel catfish, it was not clear whether these 3 isolates would affect channel catfish fingerlings. Furthermore, it was not clear whether the ECPs produced by the three 2009 isolates were lethal to channel catfish fingerlings. Therefore, this study aimed to (1) study the virulence of the three 2009 isolates of A. hydrophila to channel catfish fingerlings, compared to the virulence of a 1998 Alabama isolate of $A$. hydrophila; (2) determine the toxicity of ECPs to channel catfish fingerlings; and (3) investigate the virulence of the three 2009 isolates for channel catfish fingerlings in the presence and absence of ECPs.

\section{MATERIALS AND METHODS}

Isolation and identification of bacteria. The three 2009 isolates of Aeromonas hydrophila (AL09-71, AL09-72, AL 09-73) were obtained from diseased food-sized channel catfish from west Alabama in August 2009. The AL98-C1B isolate of A. hydrophila was isolated from diseased channel catfish in July 1998 and stored in tryptic soy broth containing 5\% glycerol at $-80^{\circ} \mathrm{C}$. All 4 isolates were cultured on tryptic soy agar (TSA) plates according to published procedures (Panangala et al. 2007) and re-isolated from channel catfish after 3 passages. The isolates were previously confirmed as A. hydrophila (Pridgeon \& Klesius 2011).

Preparation of bacterial cells and ECPs. All 4 Aeromonas hydrophila isolates were grown in tryptic soy broth (TSB) (Difco) at $28^{\circ} \mathrm{C}$ for 18 to $24 \mathrm{~h}$. The concentration (colony-forming units, $\mathrm{CFU}, \mathrm{ml}^{-1}$ ) of $A$. hydrophila used in this study was determined through serial dilutions, as described previously (Pridgeon \& Klesius 2011). For each of the 4 isolates, the procedure was as follows. To prepare A. hydrophila cells without their ECPs, $100 \mathrm{ml}$ of broth culture, with an optical density (OD) of 1.0 at $540 \mathrm{~nm}$, was centrifuged at $6000 \times g$ for $20 \mathrm{~min}$. After removing the supernatant fluid containing ECPs, the bacterial cells were resuspended in $100 \mathrm{ml}$ of fresh TSB and used for immersion or injection experiments. The supernatant fluid of the broth culture was then sterilized with a filter of pore size $0.22 \mu \mathrm{m}$ (Corning Disposable Vacuum Filtration Systems, Cole-Parmer). The sterilized supernatant was used as a source of ECPs in bath immersion and injection experiments in order to study their toxicity. The protein concentration of the ECPs from each isolate was then determined using BCA Protein assay (Pierce). Equal amounts of ECPs from each isolate were used in the toxicity studies.

Virulence of Aeromonas hydrophila cells from 4 isolates (with and without their ECPs) to channel catfish. The fish fingerlings $(4.6 \pm 1.3 \mathrm{~g})$ used in this study were obtained from catfish stocks (industry pool, initially obtained from Catfish Genetics Research Unit, Stoneville, MS) and maintained at the USDA-ARS-Aquatic Animal Health Research Unit at Auburn, Alabama. All fish were acclimated for $7 \mathrm{~d}$ prior to challenge. Acclimated fish were maintained in 571 glass aquaria under conditions described previously (Pridgeon \& Klesius 2011). All immersion experiments were performed in 21 beakers with aeration. Briefly, $100 \mathrm{ml}$ of overnight bacterial cells (OD 1.0 at $540 \mathrm{~nm}$ ), with or without overnight culture ECPs, were added to water to give a final volume of $1 \mathrm{l}$. Ten channel catfish fingerlings were immersed in each beaker for $2 \mathrm{~h}$. After the $2 \mathrm{~h}$ immersion, the catfish fingerlings were released to $57 \mathrm{l}$ glass aquaria. Mortalities were recorded daily for $7 \mathrm{~d}$ post exposure. If no mortality was observed, higher amounts $(150,200$, $300 \mathrm{ml}$ ) of overnight bacterial cells (OD 1.0 at $540 \mathrm{~nm}$ ) were used in the immersion experiments. For all the injection experiments, serially diluted cells of A. hydrophila were loaded into a $1 \mathrm{ml}$ syringe (Becton Dickinson) as described previously (Pridgeon \& Klesius 2011). A volume of $100 \mu \mathrm{l}$ was injected into each catfish fingerling. Mortalities were recorded daily for $7 \mathrm{~d}$ post exposure. The presence or absence of A. hydrophila in dead fish was determined by culturing anterior kidney samples on blood agar plates followed by API-20E (Biomérieux) biochemical analysis. Mean cumulative mortality data were analyzed by analysis of variance (ANOVA) using SigmaStat statistical analysis software (Systat Software).

Toxicity of ECPs to catfish fingerlings. To determine the toxicity of ECPs to channel catfish fingerlings by bath immersion, $100 \mathrm{ml}$ or $300 \mathrm{ml}$ of filtersterilized ECPs $\left(2.4 \mathrm{mg} \mathrm{ml}^{-1}\right)$, with or without $3 \mathrm{~h}$ incubation at room temperature, were added to 900 or $700 \mathrm{ml}$ of water, respectively. A total of 10 catfish fingerlings were immersed in the solution of ECPs (total volume 1l) for $2 \mathrm{~h}$. To determine the toxicity of ECPs to channel catfish fingerlings by intraperitoneal injection, $100 \mu \mathrm{l}$ of filter-sterilized ECPs $\left(2.4 \mathrm{mg} \mathrm{m}^{-1}\right)$, with or without $3 \mathrm{~h}$ incubation at room temperature, was injected into each fish. Ten fish were used for each Aeromonas hydrophila isolate. To understand 
whether higher amounts of ECPs would kill any fish, ECPs were concentrated using a vacufuge concentrator (Eppendorf), and 5 times the non-concentrated ECP $(1.2 \mathrm{mg}$ total $)$ of filter-sterilized ECP was injected into each fish. Immersion and injection experiments for each isolate were replicated 3 times. Mortalities were recorded daily for $7 \mathrm{~d}$ post ECP immersion or injection.

Time-course studies for the AL09-73 isolate of Aeromonas hydrophila. Of the 4 isolates, only AL0973 - in the absence of ECPs - was able to kill $100 \%$ of the fish at a concentration of $1.7 \times 10^{8} \mathrm{CFU} \mathrm{ml}{ }^{-1}$; therefore, AL09-73 was subjected to a time-course study to determine the minimum time required to kill catfish fingerlings at this concentration. Briefly, AL0973 was grown in TSB at $28^{\circ} \mathrm{C}$ for $18 \mathrm{~h}$. One hundred $\mathrm{ml}$ of broth culture (OD 1.0 at $540 \mathrm{~nm}$ ) was centrifuged at $6000 \times g$ for $20 \mathrm{~min}$. After removing the supernatant, the bacterial cells were resuspended in $100 \mathrm{ml}$ of fresh TSB, which was added to $900 \mathrm{ml}$ of water; 10 catfish fingerlings were then immersed in this bacterial suspension. At $0,15,30,45,60,75,90$, 105 and 120 min post immersion, mortality was recorded, and the presence or absence of A. hydrophila in dead fish was determined by culturing anterior kidney samples on blood agar plates followed by API20E (Biomérieux) biochemical analysis.

Bacterial dissemination in different tissues of channel catfish within $2 \mathbf{h}$ of immersion. To determine the level of bacterial dissemination in different tissues of channel catfish within $2 \mathrm{~h}$ of immersion-for AL0973 - or at $2 \mathrm{~h}$ after immersion for the other 3 isolates, 10 catfish fingerlings were subjected to bath immersion at lethal concentrations of Aeromonas hydrophila. The final concentrations of AL09-71, AL09-72, AL0973 and AL98-C1B used in this experiment were $2.1 \times$ $10^{8}, 5.3 \times 10^{8}, 1.7 \times 10^{8}$, and $1.1 \times 10^{9} \mathrm{CFU} \mathrm{ml}^{-1}$, respectively, in the absence of ECPs. Fish were washed with 11 of sterilized water 5 times, with gills open, to eliminate most of the loosely associated residual bacteria. Seven different tissues (skin, intestine, spleen, liver, kidney, gill and brain) were collected from 3 different fish for each isolate of A. hydrophila. The collected tissues were weighed, ground, and serially diluted in TSB. Serially diluted A. hydrophila suspension $(100 \mathrm{ml})$ was plated onto TSA plates. After $24 \mathrm{~h}$ incubation at $28^{\circ} \mathrm{C}$, the number of $\mathrm{CFU}$ $\mathrm{mg}^{-1}$ was calculated for each isolate of A. hydrophila in each fish tissue, and the average number was calculated from 3 fish tissues.

\section{RESULTS}

\section{Bacterial identification, and the virulence to catfish of the 4 isolates as determined by bath immersion}

All 4 isolates were identified as Aeromonas hydrophila by both biochemical and molecular identification methods (Pridgeon \& Klesius 2011). The results of the bath immersion experiments on the virulence of A. hydrophila for catfish fingerlings, in the presence and absence of ECPs, are shown in Table 1. The kidneys of all the dead fish were culture-positive for $A$. hydrophila. As shown in Table 1, the absence of ECPs significantly $(p<0.05)$ increased the virulence of all 4 isolates in the bath immersion experiments. When similar concentrations of bacteria (1.7 to $1.9 \times 10^{8} \mathrm{CFU}$ $\mathrm{ml}^{-1}$ ) were used in bath immersion experiments in the presence of ECPs, the three 2009 isolates were more virulent than AL98-C1B. When ECPs were absent in the bath immersion experiments, AL09-73 was the most virulent isolate, followed by AL09-71.

\section{Virulence of the 4 isolates (with and without ECPs) to catfish as determined by intraperitoneal injection}

Results of the intraperitoneal injection experiments on the virulence of Aeromonas hydrophila for catfish fingerlings, in the presence and absence of ECPs, are shown in Table 2. The kidneys of all the dead fish were culture-positive for $A$. hydrophila. Based on $\mathrm{LD}_{50}$ values, AL09-71, in the absence of ECPs, was less toxic compared to AL09-71 in the presence of ECPs. However, their $95 \%$ confidence intervals overlapped with each other, indicating that the virulence of AL09-71 in the presence of ECPs was not significantly higher than

Table 1. Virulence of Aeromonas hydrophila cells, with and without extracellular products (ECPs), for channel catfish as determined by bath immersion experiments. Concentration is given as colony-forming units (CFU) $\mathrm{ml}^{-1}$

\begin{tabular}{|lcccr|}
\hline $\begin{array}{l}\text { A. hydrophila } \\
\text { isolate }\end{array}$ & $\begin{array}{c}\text { Cells + ECPs } \\
\left(\mathrm{CFU} \mathrm{ml} \mathbf{~}^{-1}\right)\end{array}$ & $\begin{array}{c}\text { Mortality } \\
(\mathrm{mean} \pm \mathrm{SD}) \\
(\%)\end{array}$ & $\begin{array}{c}\text { Cells - ECPs } \\
\left(\mathrm{CFU} \mathrm{ml} \mathbf{~}^{-1}\right)\end{array}$ & $\begin{array}{c}\text { Mortality } \\
(\mathrm{mean} \pm \mathrm{SD}) \\
(\%)\end{array}$ \\
\hline AL09-71 & $1.7 \times 10^{8}$ & $20 \pm 10$ & $1.1 \times 10^{8}$ & $77 \pm 6$ \\
AL09-72 & $1.8 \times 10^{8}$ & $0 \pm 0$ & $1.5 \times 10^{8}$ & $0 \pm 0$ \\
AL09-72 & $2.7 \times 10^{8}$ & $0 \pm 0$ & $2.3 \times 10^{8}$ & $0 \pm 0$ \\
AL09-72 & $3.6 \times 10^{8}$ & $0 \pm 0$ & $3.0 \times 10^{8}$ & $0 \pm 0$ \\
AL09-72 & $5.4 \times 10^{8}$ & $13 \pm 6$ & $4.5 \times 10^{8}$ & $100 \pm 0$ \\
AL09-73 & $1.7 \times 10^{8}$ & $23 \pm 6$ & $1.6 \times 10^{8}$ & $100 \pm 0$ \\
AL98-C1B & $1.9 \times 10^{8}$ & $0 \pm 0$ & $1.8 \times 10^{8}$ & $0 \pm 0$ \\
AL98-C1B & $3.8 \times 10^{8}$ & $0 \pm 0$ & $3.6 \times 10^{8}$ & $0 \pm 0$ \\
AL98-C1B & $5.7 \times 10^{8}$ & $13 \pm 6$ & $5.4 \times 10^{8}$ & $100 \pm 0$ \\
AL98-C1B & $6.7 \times 10^{8}$ & $100 \pm 0$ & $6.3 \times 10^{8}$ & $100 \pm 0$ \\
\hline
\end{tabular}


Table 2. Virulence of Aeromonas hydrophila cells, with and without extracellular products (ECPs), for channel catfish as determined by intraperitoneal injection. $\mathrm{LD}_{50}$ and $\mathrm{LD}_{95}$ values are given in colony-forming units (CFU) per fish. Different superscript letters within columns indicate that the virulences of the A. hydrophila strains were significantly different from each other because the $95 \%$ conficence intervals (CI) failed to overlap

\begin{tabular}{|c|c|c|c|c|}
\hline A. hydrophila isolate & $\mathrm{LD}_{50}(95 \% \mathrm{CI})$ & $\mathrm{LD}_{95}(95 \% \mathrm{CI})$ & Slope (SE) & $\chi^{2}$ \\
\hline AL09-71 + ECPs & $1.6 \times 10^{3}\left(8.1 \times 10^{2}-2.4 \times 10^{3}\right)^{\mathrm{B}}$ & $7.3 \times 10^{3}\left(4.0 \times 10^{3}-5.6 \times 10^{4}\right)^{\mathrm{A}}$ & $3.33(0.74)$ & 0.22 \\
\hline AL09-71 - ECPs & $2.0 \times 10^{3}\left(1.3 \times 10^{3}-3.8 \times 10^{3}\right)^{\mathrm{B}}$ & $9.5 \times 10^{3}\left(4.6 \times 10^{3}-1.3 \times 10^{5}\right)^{\mathrm{A}}$ & $3.32(0.73)$ & 0.24 \\
\hline AL09-72 + ECPs & $5.6 \times 10^{5}\left(3.1 \times 10^{5}-1.2 \times 10^{6}\right)^{\mathrm{C}}$ & $1.1 \times 10^{7}\left(3.5 \times 10^{6}-2.1 \times 10^{8}\right)^{\mathrm{B}}$ & $3.33(0.57)$ & 0.23 \\
\hline AL09-72 - ECPs & $6.7 \times 10^{6}\left(4.4 \times 10^{6}-1.1 \times 10^{7}\right)^{\mathrm{E}}$ & $2.4 \times 10^{7}\left(1.4 \times 10^{7}-1.4 \times 10^{8}\right)^{B}$ & $3.58(0.82)$ & 0.98 \\
\hline AL09-73 + ECPs & $2.0 \times 10^{2}\left(1.1 \times 10^{2}-3.1 \times 10^{2}\right)^{\mathrm{A}}$ & $9.4 \times 10^{2}\left(5.1 \times 10^{2}-7.3 \times 10^{3}\right)^{\mathrm{A}}$ & $3.33(0.74)$ & 0.22 \\
\hline AL09-73 - ECPs & $5.2 \times 10^{2}\left(3.0 \times 10^{2}-1.0 \times 10^{3}\right)^{\mathrm{A}, \mathrm{B}}$ & $4.2 \times 10^{3}\left(1.7 \times 10^{3}-1.0 \times 10^{5}\right)^{\mathrm{A}}$ & $3.31(0.55)$ & 0.50 \\
\hline AL98-C1B + ECPs & $3.6 \times 10^{6}\left(2.7 \times 10^{6}-4.8 \times 10^{6}\right)^{\mathrm{D}}$ & $1.0 \times 10^{7}\left(6.8 \times 10^{6}-3.5 \times 10^{7}\right)^{B}$ & $3.72(0.96)$ & 0.85 \\
\hline AL98-C1B - ECPs & $3.1 \times 10^{6}\left(2.6 \times 10^{6}-3.8 \times 10^{6}\right)^{\mathrm{D}}$ & $5.6 \times 10^{6}\left(4.4 \times 10^{6}-1.1 \times 10^{7}\right)^{\mathrm{B}}$ & $3.79(1.68)$ & 0.64 \\
\hline
\end{tabular}

that of AL09-71 in the absence of ECPs. Similarly, the presence of ECPs failed to significantly increase the virulence of AL09-73 and AL98-C1B. Based on both

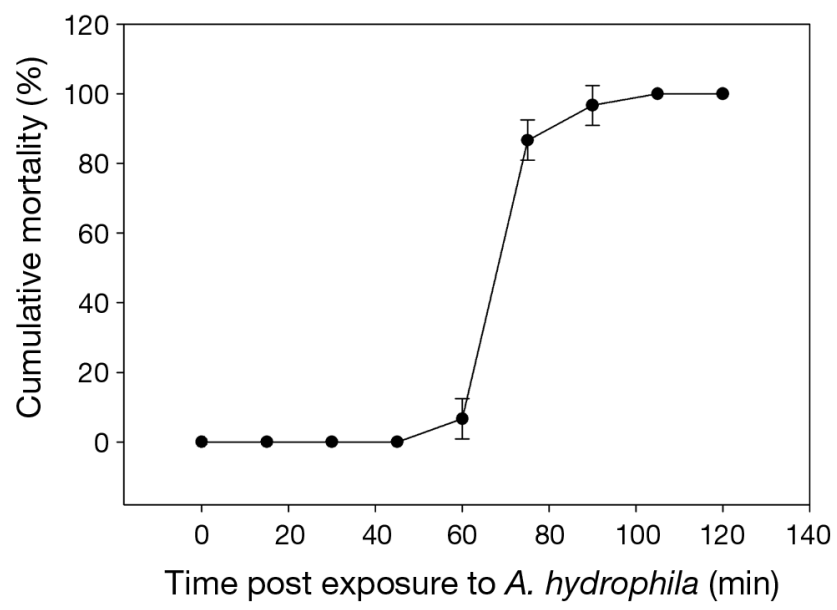

Fig. 1. Cumulative mortality at different time points after channel catfish were exposed to Aeromonas hydrophila AL09-73 by bath immersion. Mortality data are presented as mean mortality \pm SD from 3 experiments
$\mathrm{LD}_{50}$ and $\mathrm{LD}_{95}$ values (Table 2), the virulence order of the 4 isolates in the presence of ECPs was: AL09-73 $\geq$ AL09-71 > AL09-72 > AL98-C1B.

\section{Toxicity of ECPs to catfish fingerlings}

Results of studies on the toxicity of ECPs are shown in Table 3. In the bath immersion experiments, the filter-sterilized ECPs from all 4 isolates of Aeromonas hydrophila failed to kill any catfish fingerlings when used at either low or high concentrations - if the ECPs had not been incubated for $3 \mathrm{~h}$ at room temperature before use. However, after $3 \mathrm{~h}$ incubation, ECPs of AL09-72, AL09-73 and AL98-C1B at high concentration $\left(720 \mathrm{mg} \mathrm{ml}^{-1}\right)$ killed $10 \pm 0,13 \pm 6$ and $10 \pm 10 \%$ of catfish, respectively (Table 3 ). When filter-sterilized ECPs were injected into catfish, the ECPs from all isolates at a non-concentrated dose (0.24 mg) or at a concentrated dose (1.2 mg) failed to kill any fish (Table 3).
Table 3. Toxicity of Aeromonas hydrophila extracellular products (ECPs) with $(+)$ or without (-) $3 \mathrm{~h}$ incubation at room temperature to channel catfish as determined by bath immersion and intraperitoneal injection experiments. The majority of SD values are 0 as no mortality occurred in replicates

\begin{tabular}{|lcccr|}
\hline \multirow{2}{*}{$\begin{array}{l}\text { A. hydrophila } \\
\text { filter-sterilized }\end{array}$} & \multicolumn{4}{c|}{ Mean mortality } \\
\cline { 2 - 5 } ECPs & \multicolumn{3}{c|}{ Bath immersion $\left(\mathrm{mg} \mathrm{l}^{-1}\right)$} & \multicolumn{2}{c}{ Injection $(\mathrm{mg})$} \\
& 240 & 720 & 0.24 & 1.2 \\
\hline AL09-71 ECPs $-3 \mathrm{~h}$ & $0 \pm 0$ & $0 \pm 0$ & $0 \pm 0$ & $0 \pm 0$ \\
AL09-71 ECPs $+3 \mathrm{~h}$ & $0 \pm 0$ & $0 \pm 0$ & $0 \pm 0$ & $0 \pm 0$ \\
AL09-72 ECPs $-3 \mathrm{~h}$ & $0 \pm 0$ & $0 \pm 0$ & $0 \pm 0$ & $0 \pm 0$ \\
AL09-72 ECPs $+3 \mathrm{~h}$ & $0 \pm 0$ & $10 \pm 0$ & $0 \pm 0$ & $0 \pm 0$ \\
AL09-73 ECPs $-3 \mathrm{~h}$ & $0 \pm 0$ & $0 \pm 0$ & $0 \pm 0$ & $0 \pm 0$ \\
AL09-73 ECPs $+3 \mathrm{~h}$ & $0 \pm 0$ & $13 \pm 6$ & $0 \pm 0$ & $0 \pm 0$ \\
AL98-C1B ECPs $-3 \mathrm{~h}$ & $0 \pm 0$ & $0 \pm 0$ & $0 \pm 0$ & $0 \pm 0$ \\
AL98-C1B ECPs $+3 \mathrm{~h}$ & $0 \pm 0$ & $10 \pm 10$ & $0 \pm 0$ & $0 \pm 0$ \\
\hline
\end{tabular}

Time-course studies for the AL09-73 isolate of Aeromonas hydrophila

The results of time-course studies for AL09-73, in the absence of ECPs, are shown in Fig. 1. All kidney samples from the dead fish were culture-positive for A. hydrophila. As shown in Fig. 1 , no fish died at 15,30 and $45 \mathrm{~min}$ post-immersion exposure to AL09-73. At $60 \mathrm{~min}$ after exposure, $10 \%$ of the fish died in 2 experiments, and no fish died in the third experiment. At $75 \mathrm{~min}$ post exposure, $87 \pm 6 \%$ of the fish died. At 90 min post exposure, $100 \%$ of the fish died in 2 experiments, and no fish died in the third experiment. At 105 
and 120 min post exposure, all the fish died in all 3 experiments.

Concentrations of Aeromonas hydrophila in different tissues of channel catfish at $2 \mathrm{~h}$ post immersion

The concentrations of $A$. hydrophila in different tissues of channel catfish at $2 \mathrm{~h}$ post immersion are shown in Fig. 2. The highest concentrations of AL09-71, AL09-72 and AL09-73 were found in the gill, followed by kidney, liver, spleen, skin, intestine and brain. At $2 \mathrm{~h}$ post exposure to AL98-C1B, the highest bacterial concentration was in the gill, followed by skin, liver, kidney, spleen, intestine and brain (Fig. 2). Among the 4 isolates, the concentrations of bacteria in the same tissue (skin, intestine, liver, spleen, gill) were not significantly different ( $\mathrm{p}>0.05$ ) (Fig. 2). However, the concentration of the three 2009 isolates at $2 \mathrm{~h}$ post exposure was significantly higher $(p<0.05)$ than that of AL98-C1B in the kidney (Fig. 2).

\section{DISCUSSION}

In the bath immersion experiments, the presence of ECPs from overnight bacterial culture significantly reduced the virulence of all 4 isolates of Aeromonas hydrophila. However, when ECPs from overnight culture were replaced with fresh culture media (tryptic soy broth), the virulence of all 4 isolates was signifi- cantly increased, indicating that (1) bacterial cells, not their ECPs produced in vitro, are highly toxic to channel catfish, and (2) the 4 isolates of A. hydrophila can be highly lethal to channel catfish by bath immersion. Crude extracellular products of A. hydrophila N 122 (isolated from mullet Mugil cephalus), grown at 30 and $35^{\circ} \mathrm{C}$, have been reported to be lethal to tilapia by intraperitoneal injection (Khalil \& Mansour 1997). However, it is not clear whether crude extracellular products of $A$. hydrophila strain N122, grown at $28^{\circ} \mathrm{C}$ (the growth temperature of the 4 isolates in this paper), would be lethal to tilapia or channel catfish. Whether or not crude ECPs of the three 2009 Alabama isolates grown at a higher temperature would be lethal to channel catfish merits further study.

When catfish fingerlings were exposed to fresh filtersterilized ECPs by bath immersion, no fish died. However, after the ECPs had been incubated at room temperature for $3 \mathrm{~h}$, up to $20 \%$ of the fish died, suggesting that incubation at room temperature for $3 \mathrm{~h}$ somehow slightly increased the toxicity of ECPs. This slight increase could be due to activation of some toxins by the $3 \mathrm{~h}$ incubation. It has been reported that extracellular Aeromonas protease can convert the protoxin of aerolysin to a holeforming toxin which could be 250 times more hemolytic than the protoxin (Howard \& Buckley 1985). How the $3 \mathrm{~h}$ incubation at room temperature increased the toxicity of ECPs is currently unknown.

The time-course study revealed that AL09-73 was able to kill $100 \%$ of the fish within $2 \mathrm{~h}$ of exposure in the bath immersion experiments. The virulence study

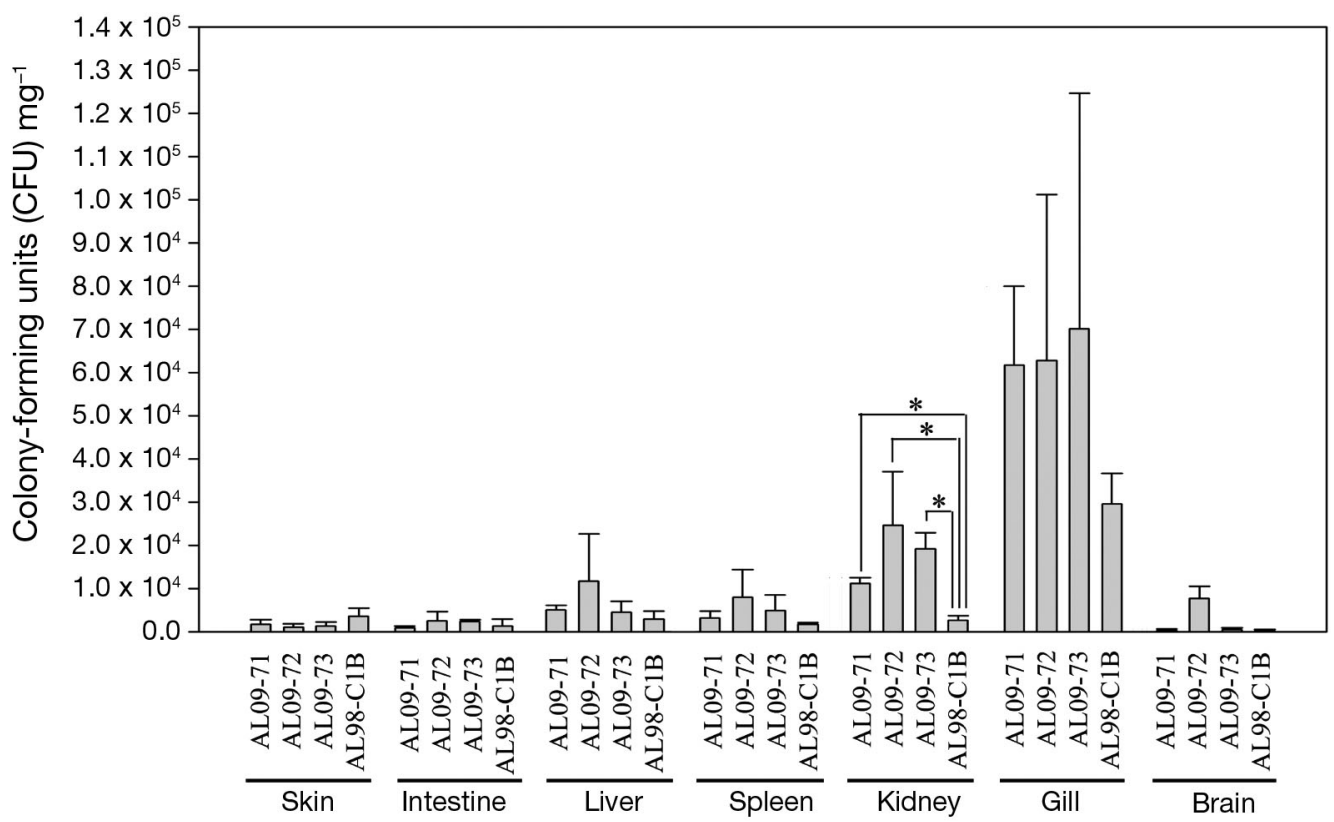

Fig. 2. Concentrations of the three 2009 isolates of Aeromonas hydrophila, compared to isolate AL98-C1B, in different tissues of channel catfish at $2 \mathrm{~h}$ after bath immersion. Results are presented as mean concentration \pm SD from 3 replicates. Significant differences $(\mathrm{p}<0.05)$ are marked by an asterisk $\left({ }^{*}\right)$ 
involving intraperitoneal injection revealed that the $\mathrm{LD}_{50}$ value of AL09-73 was only $2.0 \times 10^{2}\left(1.1 \times 10^{2}\right.$ to $3.1 \times 10^{2}$ ) CFU per fish. $\mathrm{LD}_{50}$ values of Aeromonas hydrophila isolated from diseased wild and cultured Nile tilapia have been reported to range between $10^{3}$ and $10^{7} \mathrm{CFU}$ per fish (Faisal et al. 1989). Taken together, these results suggest that AL09-73 is an extremely virulent strain of A. hydrophila.

At $2 \mathrm{~h}$ post exposure in the bath immersion experiments, the 4 isolates of Aeromonas hydrophila were distributed in all 7 tissues studied, suggesting that the infection by A. hydrophila was systemic. Studies on the pathogenesis of another strain of A. hydrophila (KJ99) have confirmed that this bacterium can be disseminated systemically in fish (Rey et al. 2009). Using green fluorescent protein as a biomarker in A. hydrophila, this bacterium has also been detected in blood, gill, kidney, liver and intestine of Crucian carp Carassius auratus gibelio at $2 \mathrm{~h}$ post bath immersion; the gills of Crucian carp were found to have the highest number of cells of A. hydrophila (Chu \& Lu 2008). We also found that gill tissue had the highest concentration of bacteria at $2 \mathrm{~h}$ post bath immersion, suggesting that gill tissue might be the main route of entry for A. hydrophila during water-borne exposure. Fish gills are structured to have only a thin layer of fragile cells separating the fish vascular system (rich in blood capillaries for respiratory functions) from the external environment, making them good portals of entry for fish pathogens. Gill has been suggested as the site of entry for other fish pathogens, such as Yersinia ruckeri (Tobback et al. 2009), Edwardsiella tarda (Ling et al. 2001) and Renibacterium salmoninarum (Campos-Perez et al. 2000), further suggesting that gill tissue might play important roles in the pathogenesis of A. hydrophila. However, the high concentrations of bacteria in gill tissue might also be due to the immersion method that resulted in high levels of bacteria remaining on the outside of gills, possibly because they are resistant to washing.

In summary, the absence of ECPs significantly increased $(\mathrm{p}<0.05)$ the virulence of the 4 isolates of Aeromonas hydrophila in the bath immersion experiments. However, the ECPs only slightly increased the virulence when bacterial cells were injected into fish intraperitoneally. When catfish fingerlings were exposed to filter-sterilized ECPs, no toxicity, or low toxicity, was observed. Time-course studies revealed that the most virulent strain, AL09-73, was able to kill $100 \%$ of the fish within $2 \mathrm{~h}$ of exposure in the bath immersion experiments. Bacterial distribution experiments revealed that the 4 strains of A. hydrophia were disseminated in all 7 tissues studied within $2 \mathrm{~h}$ of exposure in the bath immersion experiments. Among the 7 tissues studied, gill tissue consistently had the highest concentration of bacteria.
Acknowledgements. We thank H.-Y. Yeh (USDA-ARS) and V. Panangala (USDA collaborator) for critical reviews of the manuscript. We thank W. Hemstreet (Alabama Fish Farming Center), J. Terhune (Auburn University), and J. Bebak (USDA-ARS) for obtaining the 32009 isolates of A. hydrophila. We thank B. Peterman (USDA-ARS) for her excellent technical support. We thank B. Scheffler and F. Liu (USDAARS-Catfish Genetics Research Unit) for their excellent sequencing work. We also thank the management team of the Aquatic Animal Health Research Unit for daily care and management of the fish. This study was supported by the USDA/ ARS CRIS project \#6420-32000-024-00D. The use of trade, firm, or corporate names in this publication is for the information and convenience of the reader. Such use does not constitute an official endorsement or approval by the United States Department of Agriculture or the Agricultural Research Service of any product or service to the exclusion of others that may be suitable.

\section{LITERATURE CITED}

Abd-El-Rhman AM (2009) Antagonism of Aeromonas hydrophila by propolis and its effect on the performance of Nile tilapia, Oreochromis niloticus. Fish Shellfish Immunol 27: $454-459$

Azad IS, Rajendran KV, Rajan JJS, Vijayan KK, Santiago TC (2001) Virulence and histopathology of Aeromonas hydrophila (Sah 93) in experimentally infected tilapia, Oreochromis mossambicus (L.). J Aquac Trop 16:265-275

Campos-Perez JJ, Ward M, Grabowski PS, Ellis AE, Secombes CJ (2000) The gills are an important site of iNOS expression in rainbow trout Oncorhynchus mykiss after challenge with the gram-positive pathogen Renibacterium salmoninarum. Immunology 99:153-161

Chu WH, Lu CP (2008) In vivo fish models for visualizing Aeromonas hydrophila invasion pathway using GFP as a biomarker. Aquaculture 277:152-155

- Esteve C, Amaro C, Toranzo AE (1994) O-serogrouping and surface components of Aeromonas hydrophila and Aeromonas jandaei pathogenic for eels. FEMS Microbiol Lett 117:85-90

Faisal M, Popp W, Refai M (1989) Aeromonas hydrophilarelated septicemia in the Nile tilapia Oreochromis niloticus. Berl Munch Tierarztl Wochenschr 102:87-93

Fang HM, Ge R, Sin YM (2004) Cloning, characterisation and expression of Aeromonas hydrophila major adhesin. Fish Shellfish Immunol 16:645-658

Harikrishnan R, Nisha Rani M, Balasundaram C (2003) Hematological and biochemical parameters in common carp, Cyprinus carpio, following herbal treatment for Aeromonas hydrophila infection. Aquaculture 221:41-50

Harikrishnan R, Balasundaram C, Heo MS (2009) Effect of chemotherapy, vaccines and immunostimulants on innate immunity of goldfish infected with Aeromonas hydrophila. Dis Aquat Org 88:45-54

Hemstreet B (2010) An update on Aeromonas hydrophila from a fish health specialist for summer 2010. Catfish J $24: 4$

Howard SP, Buckley JT (1985) Activation of the hole-forming toxin aerolysin by extracellular processing. J Bacteriol 163:336-340

Irianto A, Robertson PA, Austin B (2003) Oral administration of formalin-inactivated cells of Aeromonas hydrophila A3-51 controls infection by atypical A. salmonicida in goldfish, Carassius auratus (L.). J Fish Dis 26: $117-120$ 
Jeney Z, Rácz T, Thompson KD, Poobalane S, Ardó L, Adams A, Jeney $G$ (2009) Differences in the antibody response and survival of genetically different varieties of common carp (Cyprinus carpio L.) vaccinated with a commercial Aeromonas salmonicida/A. hydrophila vaccine and challenged with A. hydrophila. Fish Physiol Biochem 35: 677-682

Karunasagar I, Rosalind GM, Karunasagar I, Gopal Rao K (1989) Aeromonas hydrophila septicaemia of Indian major carps in some commercial fish farms of West Godavari District, Andhra Pradesh. Curr Sci 58:1044-1045

Khalil AH, Mansour EH (1997) Toxicity of crude extracellular products of Aeromonas hydrophila in tilapia, Tilapia nilotica. Lett Appl Microbiol 25:269-273

Ling SH, Wang XH, Lim TM, Leung KY (2001) Green fluorescent protein-tagged Edwardsiella tarda reveals portal of entry in fish. FEMS Microbiol Lett 194:239-243

Majumdar T, Datta S, Ghosh D, Dutta S, Chakraborty A, Goswami R, Mazumder S (2007) Role of virulence plasmid of Aeromonas hydrophila in the pathogenesis of ulcerative disease syndrome in Clarias batrachus. Indian J Biochem Biophys 44:401-406

Mastan SA, Qureshi TA (2001) Role of bacteria in the epizootic ulcerative syndrome (EUS) of fishes. J Environ Biol 22:187-192

Nielsen ME, Høi L, Schmidt AS, Qian D, Shimada T, Shen JY, Larsen JL (2001) Is Aeromonas hydrophila the dominant motile Aeromonas species that causes disease outbreaks in aquaculture production in the Zhejiang Province of China? Dis Aquat Org 46:23-29

Panangala VS, Shoemaker CA, Van Santen VL, Dybvig K, Klesius PH (2007) Multiplex PCR for simultaneous detection of 3 bacterial fish pathogens, Flavobacterium columnare, Edwardsiella ictaluri, and Aeromonas hydrophila. Dis Aquat Org 74:199-208

Editorial responsibility: V. Gregory Chinchar, Jackson, Mississippi, USA
Pridgeon JW, Klesius PH (2011) Molecular identification and virulence of three Aeromonas hydrophila isolates cultured from infected channel catfish during a disease outbreak in west Alabama (USA) in 2009. Dis Aquat Org 94: 249-253

> Rey A, Verján N, Ferguson HW, Iregui C (2009) Pathogenesis of Aeromonas hydrophila strain KJ99 infection and its extracellular products in two species of fish. Vet Rec 164: 493-499

Rivero O, Anguita J, Paniagua C, Naharro G (1990) Molecular cloning and characterization of an extracellular protease gene from Aeromonas hydrophila. J Bacteriol 172: 3905-3908

Tellez-Bañuelos MC, Santerre A, Casas-Solis J, Zaitseva G (2010) Endosulfan increases seric interleukin-2-like (IL2L) factor and immunoglobulin $\mathrm{M}(\mathrm{IgM})$ of Nile tilapia (Oreochromis niloticus) challenged with Aeromona hydrophila. Fish Shellfish Immunol 28:401-405

Thorpe JE, Roberts RJ (1972) Aeromonad epidemic in brown trout (Salmo trutta (L.). J Fish Biol 4:441-541

Tobback E, Decostere A, Hermans K, Ryckaert J, Duchateau L, Haesebrouck F, Chiers K (2009) Route of entry and tissue distribution of Yersinia ruckeri in experimentally infected rainbow trout Oncorhynchus mykiss. Dis Aquat Org 84:219-228

Ullal AJ, Litaker RW, Noga EJ (2008) Antimicrobial peptides derived from hemoglobin are expressed in epithelium of channel catfish (Ictalurus punctatus, Rafinesque). Dev Comp Immunol 32:1301-1312

Yin G, Ardó L, Thompson KD, Adams A, Jeney Z, Jeney G (2009) Chinese herbs (Astragalus radix and Ganoderma lucidum) enhance immune response of carp, Cyprinus carpio, and protection against Aeromonas hydrophila. Fish Shellfish Immunol 26:140-145

Submitted: November 22, 2010; Accepted: March 12, 2011 Proofs received from author(s): May 31, 2011 